\title{
Primary Pyomyositis Mimicking Transient Synovitis of the Hip in a Child: A Case Report
}

\author{
Çocukta Kalçada Geçici Sinoviti Taklit Eden Primer Piyomiyozit: \\ Olgu Sunumu
}

\author{
Salih KAVUKÇU, ${ }^{1}$ Can KOŞAY, ${ }^{2}$ Handan ÇAKMAKÇI, ${ }^{3}$ Yeşim ÖZTÜRK, ${ }^{1}$ Özden ANAL ${ }^{1}$ \\ ${ }^{1}$ Department of Pediatrics, Medical Faculty of Dokuz Eylül University, İzmir, Turkey; \\ ${ }^{2}$ Department of Orthopedics and Traumatology, Medical Faculty of Dokuz Eylül University, İzmir, Turkey; \\ ${ }^{3}$ Department of Radiology, Medical Faculty of Dokuz Eylül University, İzmir, Turkey
}

\begin{abstract}
Pyomyositis, which is an uncommon pyogenic infection of skeletal muscle, is a rare, but potentially serious disease in children. Pyomyositis can be easily confused with more benign conditions, thus serious complications including compartment syndrome, contiguous osteomyelitis, extension into and destruction of an adjacent joint, sepsis and death may occur. Early diagnosis established with magnetic resonance imaging or computed tomography, prompt drainage of the abscess, microbiological studies and appropriate intravenous antibiotic treatment prevent complications and provide successful management of pyomyositis in children. In this paper, we present a case with gluteal pyomyositis who was initially misdiagnosed as transient synovitis and suffered from contiguous osteomyelitis due to delay in diagnosis.
\end{abstract}

Key words: Children; osteomyelitis; pyomiyositis, S. aureus.

Pyomyositis (PM) is a primary suppurative infection of the skeletal muscle which ${ }^{[1]}$ was initially found in the tropics but is increasingly seen in temperate areas. It is actually not as "rare" as it once was thought to be. Perhaps this is because of increased recognition, better imaging modalities, and the larger number of immunosuppressed hosts in temperate areas. ${ }^{[2-4]}$ Pyomyositis is classically described as a disease which occurs in young, healthy individuals, ${ }^{[5,6]}$ and the incidence is on the increase worldwide among children
İskelet kasının sık rastlanmayan piyojenik enfeksiyonu olan piyomiyozit, çocuklarda nadir görülen, fakat ciddi seyredebilen bir hastalıktır. Piyomiyozit benign hastalıklarla kolaylıkla karıştırılabileceği için, kompartman sendromu, komşu eklemde osteomiyelit, bitişik eklemin ekstansiyonu ve yıkımı, sepsis ve ölüme yol açabilir. Manyetik rezonans görüntüleme veya bilgisayarlı tomografi ile konulan erken tanı, apsenin hızlı drenajı, mikrobiyolojik çalışmalar ve uygun intravenöz antibiyotik tedavisi ile çocuklarda komplikasyonlar önlenebilir ve piyomiyozit başarılı bir şekilde tedavi edilebilir. Bu yazıda, ilk olarak geçici sinovit yanlış tanısı konan ve tanıda gecikme yaşandığı için komşu eklemde osteomiyelit gelişen, bir gluteal piyomiyozit olgusu sunuldu.

Anahtar sözcükler: Çocuklar; osteomiyelit; piyomiyozit; S. aureus.

and adults. ${ }^{[4,7,8]}$ Underlying conditions associated with PM include trauma, infection, malnutrition, diabetes mellitus, malignancy, human immunodeficiency virus (HIV) infection, inflammatory bowel disease (IBD), autoimmune disease, chronic liver diseases, rheumatological conditions, and a history of intravenous drug abuse. ${ }^{[4,8-10]}$ Because of its often vague clinical presentation, the diagnosis of pyomyositis can be delayed, which may result in a compartment syndrome, extension into and destruction of an

\footnotetext{
Received: March 11, 2011 Accepted: September 05, 2011

Correspondence: Salih Kavukçu, M.D. Dokuz Eylül Üniversitesi Tıp Fakültesi Çocuk Sağı̆̆ı ve Hastalıkları Anabilim Dalı, 35210 Alsancak, İzmir, Turkey. Tel: +90 232 - 4123650 e-mail: s.kavukcu@deu.edu.tr

(C2012 Turkish League Against Rheumatism. All rights reserved.
} 
adjacent joint, sepsis, and, occasionally, death. ${ }^{[11-14]}$ Herein, we report a case with gluteal PM at the early invasive stage. A misdiagnosis of transient synovitis and occurrence of contiguous osteomyelitis due to the delay in diagnosis is presented. The clinical and laboratory features of PM are also reviewed.

\section{CASE REPORT}

A nine-year-old boy presented to the rheumatology outpatient clinic with left hip pain and a poor appetite which had persisted for two days. The pain was exacerbated when weight was beared on the left leg. The patient had no fever, local tenderness, or swelling. He had no symptoms in other joints, no sore throat, earache, or recent illness, nor had he recently traveled. He had a history of suspicious trauma to his left leg which had occurred five days before his visit to the clinic. He had also had recurrent abdominal pain for three years. On physical examination, the patient was in severe discomfort and experienced difficulty in walking due to the pain in his leg. His vital signs were as follows: a temperature of $37.6{ }^{\circ} \mathrm{C}$, a pulse rate of 78 beats/min, a respiratory rate of $22 \mathrm{~min}$, and blood pressure of $100 / 60 \mathrm{mmHg}$. His body weight and height were in the $75^{\text {th }}-90^{\text {th }}$ percentile. There was no redness, swelling, or warmth in the left groin, and no inguinal lymphadenopathy was observed. The movements of the left hip, especially rotations, were painful but not severely limited. Abdominal and neurological examinations were normal.

A laboratory examination revealed a white blood cell count of 19.000 cells $/ \mathrm{mm}^{3}$, with $74 \%$ neutrophils. The hematocrit was $37.5 \mathrm{~g} / \mathrm{dL}$, the hemoglobin was $13.4 \mathrm{~g} / \mathrm{dL}$, the C-reactive protein (CRP) was $6.87 \mathrm{mg} / \mathrm{L}$, and the erythrocyte sedimentation rate (ESR) was

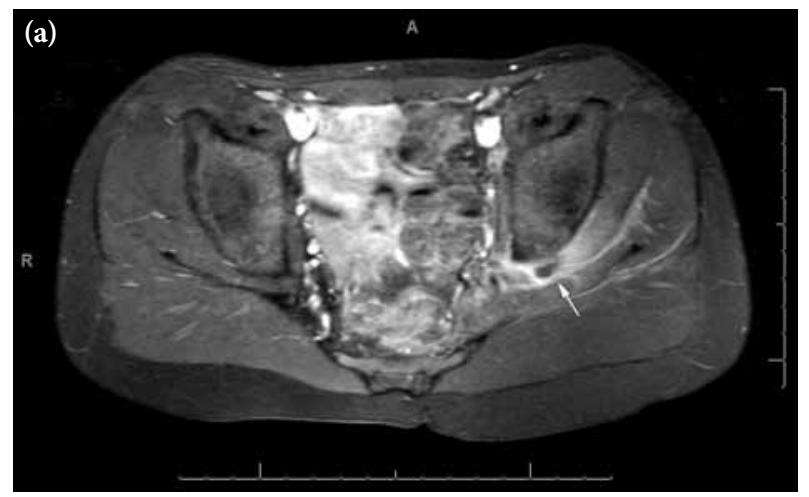

Figure 1. Contrast-enhanced pelvic MRI images, [(a) axial, (b) coronal] revealing the enhanced left-sided, deep-seated gluteal soft tissue infection (arrow in b) and peripherallyenhanced area of abscess (arrow in a).
$36 \mathrm{~mm} / \mathrm{h}$. The urinalysis, renal function, serum glucose, electrolyte, and creatine phosphokinase levels were normal. The test for HIV was negative, and an abdominal ultrasound was unremarkable. At the beginning, he was diagnosed as having transient synovitis. He was prescribed naproxen, and there was mild clinical improvement. Five days later, contrastenhanced magnetic resonance imaging (MRI) of the pelvis and hips revealed a left-sided, deep-seated gluteal fluid collection consistent with an abscess (Figure 1). The patient was administered intravenous cephazolin and metronidazol. On the ninth day, in addition to the gluteal deep soft tissue abscess, focal osteomyelitis in the posterior of the left acetabulum was detected (Figure 2). Echocardiographic findings were normal, and blood cultures were negative. A combination of vancomycin and amikacin was started instead of the cephazolin and metronidazol. On the $10^{\text {th }}$ day, he underwent an incision, and the left glutean abscess was drained. Staphylococcus aureus (S. aureus) was isolated from the pus culture, and osteomyelitis was confirmed histologically. Because of abdominal pain, a colonoscopy was performed to exclude IBD, but normal colonoscopy findings were observed. The intravenous antibiotics were continued for six weeks, after which time he had completely recovered.

\section{DISCUSSION}

Pyomyositis is an acute, deep skeletal muscle infection seen especially in Africa and South Pacific. ${ }^{[2,15,16]}$ The exact etiology is not clear. It can occur in any age group, although it is more common in the first and second decades of life. ${ }^{[17]}$

Bacterial infection is rare in the skeletal muscle, which is usually resistant to infection. ${ }^{[7,8,18]}$ It has

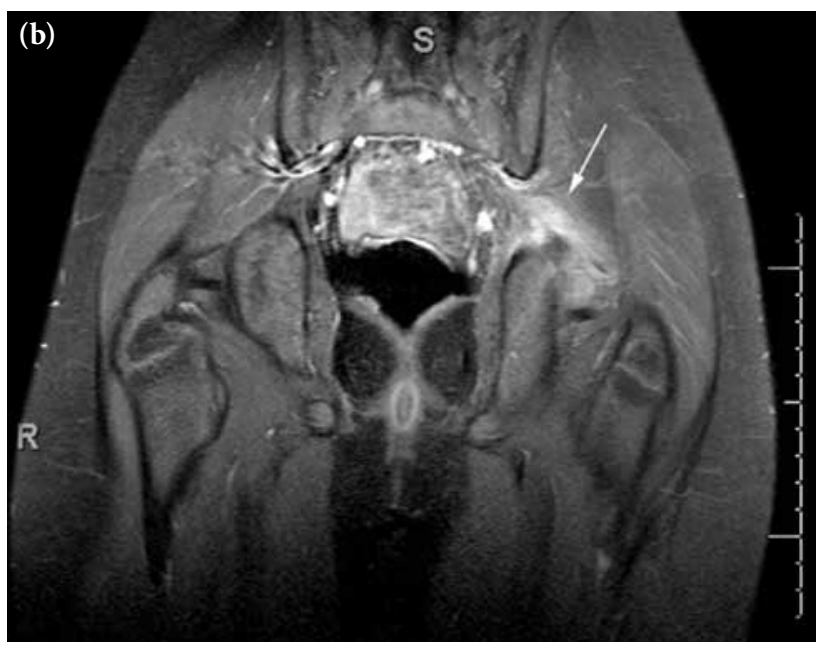




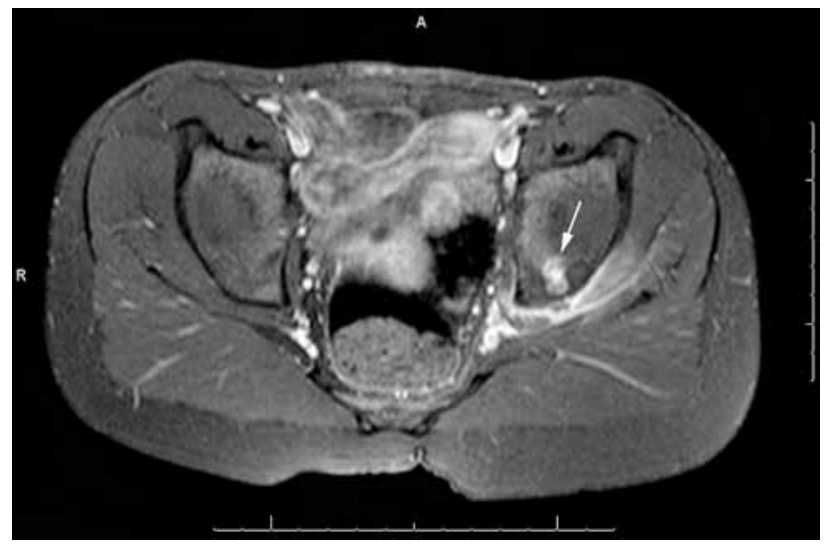

Figure 2. Contrast-enhanced pelvic magnetic resonance imaging axial image showing the enhanced left-sided, deepseated gluteal soft tissue infection and the iliac bone focal osteomyelitis (arrow).

been suggested that in order for PM to develop, some alterations in the usual defenses of the affected muscle are necessary. Trauma has been postulated to contribute to PM by facilitating hematogenous access to the muscle tissue and by providing an iron-enriched environment for bacterial growth through the release of myoglobin. ${ }^{[7,18]}$ The source of the bacterial inoculum is believed to be either from distant skin infections with transient bacteriemia or, less commonly, from local vascular or lymphatic contamination. ${ }^{[4,7,18,19]}$ Children seldom have preexisting conditions compared with adults. ${ }^{[2,10,16,20]}$ In the paper by Unnikrishnan et al. ${ }^{[17]}$ only two of 13 pediatric patients with PM had any pre-existing medical problems (asthma, juvenile arthritis), and these were not directly linked to PM. The association of trauma at the time of bacteriemia has been postulated to explain the increased risk of developing pyomyositis. ${ }^{[17]}$ Our patient also had a suspicious trauma history. It has been reported that $S$. aureus is the most common pathogen in PM. ${ }^{[4,7,18]}$ This was the same microorganism isolated from the pus material of our patient. Because of his chronic abdominal pain, we investigated the colon regarding IBD, a probable cause of PM, but the colonoscopy results were normal. Therefore, a definite etiology could not be identified in this patient.

Pyomyositis usually occurs in proximal muscle groups, including the quadriceps, iliopsoas, gluteus, calf, shoulder, and upper arm muscles. either in single form or in multiple groups. ${ }^{[4,7,18]}$ Our case presented with gluteal localization of PM, which is reported frequently in the involved area.
Threeclinicalstages of PMhavebeen described. ${ }^{[1,17,18]}$ In the early invasive stage, pain and mild swelling of the involved muscles are the first signs of PM. Because the muscle abscess is contained by overlying fascia, local erythema and heat may be minimal until days or even weeks after symptom onset. Localized signs and symptoms can precede systemic manifestation by weeks. Next, the suppurative stage occurs 10-21 days after symptom onset and includes fever, malaise, leukocytosis, elevated ESR, and anemia. In this stage, the affected muscles become very tender and edematous. After abscess formation, the involved muscles typically become fluctuant. If the infection is not recognized and treated in this stage, PM can progress to the third septicemic stage. Toxicity and bacteriemia are found in this last stage along with the formation of metastatic abscesses, and abscess complications such as septic shock, endocarditis, myocarditis, pericarditis, pneumonia, lung and brain abscess, renal failure, rhabdomyolysis, and compartment syndrome may develop. ${ }^{[1,4,7,18]}$

The potential complications are secondary to delayed presentation. The vast majority of patients show excellent and complete recovery with no longterm complications. ${ }^{[17]}$ However, it has been determined that most of PM patients present during the suppurative stage..$^{[4,17,18]}$

Although approximately $90 \%$ of PM patients present during the suppurative stage, our patient presented in the first stage. ${ }^{[4,18]}$ However, the opportunity for early diagnosis was missed, and the delay resulted in the contiguous osteomyelitis. It has been previously suggested that CT scans and MRIs are useful imaging techniques for early diagnosis of PM instead of relying solely on X-rays. ${ }^{[18,21]}$ We believe the complication in our case could have been prevented if an MRI had been performed earlier. Treatment with antibiotics alone may be sufficient in the first stage of $\mathrm{PM},{ }^{[4,8]}$ but the delay in diagnosis in our case probably resulted in the abscess drainage and osteomyelitis complication.

We conclude that early diagnosis, established via an MRI or CT scan, prompt drainage of any abscess, microbiological studies, and appropriate intravenous antibiotic treatment provide successful management of PM in children.

\section{Declaration of conflicting interests}

The authors declared no conflicts of interest with respect to the authorship and/or publication of this article. 


\section{Funding}

The authors received no financial support for the research and/or authorship of this article.

\section{REFERENCES}

1. Torralba KD, Quismorio FP Jr. Soft tissue infections. Rheum Dis Clin North Am 2009;35:45-62.

2. Chiedozi LC. Pyomyositis. Review of 205 cases in 112 patients. Am J Surg 1979;137:255-9.

3. Papadopoulos M, Chugh S, Fitzgerald R, Thomas RJ. Obturator internus pyomyositis. Orthopedics 2000;23:383-4.

4. Crum NF. Bacterial pyomyositis in the United States. Am J Med 2004;117:420-8.

5. Small LN, Ross JJ. Tropical and temperate pyomyositis. Infect Dis Clin North Am 2005;19:981-9.

6. Birkbeck D, Watson JT. Obturator internus pyomyositis. A case report. Clin Orthop Relat Res 1995;316:221-6.

7. Gibson RK, Rosenthal SJ, Lukert BP. Pyomyositis. Increasing recognition in temperate climates. Am J Med 1984;77:768-72.

8. Larkin JA, Shashy RG, Poblete SJP. Nontropical Pyomyositis. Hosp Physician 1999;35:67-71.

9. Walling DM, Kaelin WG Jr. Pyomyositis in patients with diabetes mellitus. Rev Infect Dis 1991;13:797-802.

10. Brown JD, Wheeler B. Pyomyositis. Report of 18 cases in Hawaii. Arch Intern Med 1984;144:1749-51.

11. Freedman KB, Hahn GV, Fitzgerald RH Jr. Unusual case of septic arthritis of the hip: spread from adjacent adductor pyomyositis. J Arthroplasty 1999;14:886-91.
12. Harrington $P, S \operatorname{Sctt} B$, Chetcuti P. Multifocal streptococcal pyomyositis complicated by acute compartment syndrome: case report. J Pediatr Orthop B 2001;10:120-2.

13. Immerman RP, Greenman RL. Toxic shock syndrome associated with pyomyositis caused by a strain of Staphylococcus aureus that does not produce toxic-shocksyndrome toxin-1. J Infect Dis 1987;156:505-7.

14. Ovadia D, Ezra E, Ben-Sira L, Kessler A, Bickels J, Keret $\mathrm{D}$, et al. Primary pyomyositis in children: a retrospective analysis of 11 cases. J Pediatr Orthop B 2007;16:153-9.

15. Bickels J, Ben-Sira L, Kessler A, Wientroub S. Primary pyomyositis. J Bone Joint Surg [Am] 2002;84:2277-86.

16. Levin MJ, Gardner P, Waldvogel FA. An unusual infection due to staphylococcus aureus. N Engl J Med 1971;284:196-8.

17. Unnikrishnan PN, Perry DC, George H, Bassi R, Bruce CE. Tropical primary pyomyositis in children of the UK: an emerging medical challenge. Int Orthop 2010;34:109-13.

18. Lemonick DM. Non-tropical pyomyositis caused by methicillin-resistant Staphylococcus aureus: an unusual cause of bilateral leg pain. J Emerg Med 2012;42:e55-62.

19. Crossley M. Temperate pyomyositis in an injecting drug misuser. A difficult diagnosis in a difficult patient. Emerg Med J 2003;20:299-300.

20. Karmazyn B, Kleiman MB, Buckwalter K, Loder RT, Siddiqui A, Applegate KE. Acute pyomyositis of the pelvis: the spectrum of clinical presentations and MR findings. Pediatr Radiol 2006;36:338-43.

21. Soler R, Rodríguez E, Aguilera C, Fernández R. Magnetic resonance imaging of pyomyositis in 43 cases. Eur J Radiol 2000;35:59-64. 